\title{
CC10 Reduces Inflammation in Meconium Aspiration Syndrome in Newborn Piglets
}

\author{
ROBERT M. ANGERT, APRILE L. PILON, DARRIN CHESTER, AND JONATHAN M. DAVIS
}

\begin{abstract}
Department of Pediatrics [R.M.A., D.C.], The CardioPulmonary Research Institute, Winthrop University Hospital, SUNY Stony Brook School of Medicine, Mineola, New York 11501; Claragen Corporation [A.L.P.], Germantown, Maryland 20874; Tufts-New England Medical Center [J.M.D.], Boston, Massachusetts 02222
\end{abstract}

\begin{abstract}
Complications from meconium aspiration syndrome (MAS) remain significant despite a variety of therapeutic interventions. Clara cell protein (CC10) is a novel anti-inflammatory agent that can also inhibit phospholipase $\mathrm{A}_{2}\left(\mathrm{PLA}_{2}\right.$ ) (an important component of meconium). The present study examined whether administration of recombinant human $\mathrm{CC} 10$ (rhCC10) would reduce inflammation and improve lung function in a piglet model of MAS. Following meconium instillation, piglets exhibited significant physiologic dysfunction that improved significantly after surfactant administration. Analysis of tracheal aspirates revealed significant increases in both tumor necrosis factor (TNF) $\alpha$ and interleukin (IL)- 8 after meconium instillation. rhCC10-treated animals had significantly lower TNF- $\alpha$ levels at $24 \mathrm{~h}(561 \pm 321$ versus $1357 \pm 675 \mathrm{pg} / \mathrm{mL}$, $p<0.05)$ compared with saline controls. There were no differences between rhCC10-treated and untreated groups with respect to other measured physiologic variables or inflammatory markers, including secretory $\mathrm{PLA}_{2}$ activity. Histologic analyses revealed marked inflammatory infiltrates and thickened alveolar walls, but no significant differences among rhCC10 and control animals. Newborn piglets with MAS have significant physiologic dysfunction, marked inflammatory changes and histologic abnormalities, which was partially counteracted by a single dose of exogenous surfactant and rhCC10. (Pediatr Res 62: 684-688, 2007)
\end{abstract}

$\mathrm{M}^{\mathrm{c}}$ erconium aspiration syndrome (MAS) can be a devastating illness that primarily affects full-term newborns. It is a multifaceted process that leads to significant mechanical, chemical, and immunologic dysfunction. Despite substantial advances in obstetrical and neonatal care, morbidity and mortality remain unacceptably high (1). The pathophysiology of MAS is often divided into two phases: an early phase characterized by airway obstruction (related to the particulate nature of meconium) and later effects involving severe inflammation (from chemical pneumonitis) and surfactant inactivation (2). Endogenous surfactant function is inhibited by a variety of constituents of meconium, including phospholipases (PLAs) that destroy endogenous surfactant and contribute to the inflammatory response seen in MAS (3). Other effects of meconium include direct lung epithelial cell damage by phospholipase $\mathrm{A}_{2}$ $\left(\mathrm{PLA}_{2}\right)$ with the release of TNF- $\alpha$ (4). All these factors interact synergistically to cause significant lung injury in the newborn.

Received March 14, 2007; accepted July 21, 2007.

Correspondence: Robert Angert, M.D., Department of Pediatrics, Winthrop, University Hospital, SUNY Stony Brook School of Medicine, 259 First Street, Mineola, NY 11501; e-mail: rangert@winthrop.org

This work was funded by National Heart Lung and Blood Institute, National Institutes of Health, Bethesda, MD (NHLBI R43 HL073572).
Interventions designed to mitigate the proinflammatory effects of meconium have met with limited success. Although corticosteroids have been studied in multiple clinical trials, a 2003 Cochrane Review concluded that there was no significant affect on mortality or morbidity (5). This suggests that other anti-inflammatory therapies that might also enhance surfactant function may be beneficial in MAS.

Clara cell protein $(\mathrm{CC10})$ is a novel anti-inflammatory protein that is known to inhibit the activity of secretory $\mathrm{PLA}_{2}$ $\left(\mathrm{sPLA}_{2}\right)$ in vitro, notably the pancreatic or type $1 \mathrm{~b}$ enzyme and the macrophage-derived or type $2 \mathrm{a}$ enzyme (6). CC10 deficiency plays a vital role in a variety of disease processes including bronchopulmonary dysplasia, acute respiratory distress syndrome, asthma, cystic fibrosis, renal disease, and cancer (7). While one strain of mice genetically engineered to reduce $\mathrm{CC} 10$ activity develops glomerulopathy, pancreatic inflammation, and cancer soon after birth (8), another strain has increased lung injury in response to hyperoxia or infection (9). Recombinant human clara cell protein (rhCC10) has been shown to effectively decrease lung inflammation in a variety of animal models via the intravenous (i.v.) or intratracheal (i.t.) route (10-12). In addition, human trials in premature infants at risk of developing acute and chronic lung injury (also characterized by significant inflammatory changes in the lung) demonstrate significant reductions in several important inflammatory mediators in the lung of infants receiving rhCC10 compared with placebo controls (13). These studies suggest that $\mathrm{CC} 10$ plays an important role in normal organ function.

Since rhCC10 appears to have significant anti-inflammatory properties and inhibits $\mathrm{PLA}_{2}$ activity in vitro, we hypothesized that i.t. administration in a piglet model of MAS would reduce inflammation and minimize acute lung injury, primarily by inhibiting $\mathrm{PLA}_{2}$ activity in vivo. This hypothesis was tested in a well-established model of MAS in newborn piglets.

\section{METHODS}

Studies were approved by the Institutional Animal Care and Use Committee (IACUC). Sixteen 1- to 3-d-old piglets were sedated with intraperitoneal

Abbreviations: BAL, bronchoalveolar lavage; CC10, Clara cell protein; it, intratracheal; MAS, meconium aspiration syndrome; PLA 2 , phospholipase $\mathrm{A}_{2}$; rhCC10, recombinant human Clara cell protein; $\mathbf{S P L A _ { 2 }}$, secretory phospholipase $\mathrm{A}_{2}$; TAF, tracheal aspirate fluid 
sodium pentobarbital $(30 \mathrm{mg} / \mathrm{kg})$, placed on a heating blanket, and intubated with a 3.5- to 4.0-mm endotracheal tube, and a 3.5-F umbilical arterial line was inserted. Mechanical ventilation was begun using a Bear Cub infant ventilator (VIASYS Healthcare, Palm Springs, CA) with positive endexpiratory pressure (PEEP) of $3 \mathrm{~cm} \mathrm{H}_{2} \mathrm{O}$, inspiratory time of $0.5 \mathrm{~s}$., and a flow rate of $8 \mathrm{~L} / \mathrm{min}$. Peak inspiratory pressure and ventilatory rate were varied to maintain partial pressure of carbon dioxide $\left(\mathrm{PCO}_{2}\right)$ at $40-50 \mathrm{~mm} \mathrm{Hg}$. Blood gases were measured every 3-4 h using a Gem Premier 3000 blood gas analyzer (Lexington, MA). Five percent dextrose with 0.33 normal saline was administered at $80 \mathrm{~mL} / \mathrm{kg} / \mathrm{d}$. Ampicillin $(50 \mathrm{mg} / \mathrm{kg})$ and gentamicin $(2.5$ $\mathrm{mg} / \mathrm{kg}$ ) were given every $12 \mathrm{~h}$. Additional pentobarbital was administered as needed to maintain sedation. Arterial/alveolar oxygen ratios were calculated before and after meconium instillation, 1-2 $\mathrm{h}$ after surfactant administration and at $24 \mathrm{~h}$.

Meconium from healthy newborns $[3 \mathrm{~mL} / \mathrm{kg}, 20 \%$ by weight in phosphatebuffered saline (PBS)] was filtered to remove large particulate matter and instilled via the endotracheal tube as previously described (14). Oxygen and mechanical ventilation were then adjusted to maintain arterial blood gases in the physiologic range (with PEEP increased to $4 \mathrm{~cm} \mathrm{H}_{2} \mathrm{O}$ ). After $30 \mathrm{~min}$, animals received $4 \mathrm{~mL} / \mathrm{kg}$ of surfactant (Survanta, Ross Laboratories, Columbus, $\mathrm{OH}$ ). Twenty minutes later, half of the piglets received i.t. normal saline (placebo) alone $(2 \mathrm{~mL} / \mathrm{kg})$, while the other half were given i.t. rhCC10. rhCC10 ( $5 \mathrm{mg} / \mathrm{kg}$ diluted to a total volume of $2 \mathrm{~mL} / \mathrm{kg}$ with normal saline) was instilled with the piglets in a 30-degree Trendelenberg (head-down) position in two divided doses in the left and right lateral decubitus positions. The rhCC10 was produced in Escherichia coli bacteria according to published methods (Claragen, Inc., Germantown, MD) (15). The protein for the study was a $>98 \%$ pure solution of the human $\mathrm{CC} 10$ homodimer. The biologic activity of each batch was compared using a previously published secretory $\mathrm{PLA}_{2}$ inhibition assay for rhCC10 (15).

At baseline and $24 \mathrm{~h}$, tracheal aspirate fluid (TAF) samples were obtained as previously described (14). At $24 \mathrm{~h}$, piglets were given pentobarbital (30 $\mathrm{mg} / \mathrm{kg}$ ), and static pressure-volume curves were generated as previously described (15). Two piglets in each group were used for histologic analysis. A catheter was secured in the pulmonary artery and an incision made in the left atrium. The vascular system was infused with $180 \mathrm{~mL}$ of normal saline followed by $180 \mathrm{~mL}$ of $10 \%$ formalin. The lungs were then removed en bloc. Tissue was paraffin embedded and sections stained with hematoxylin and eosin. Remaining tissues were prepared as above without the formalin fixation. After removal, bronchial alveolar lavage (BAL) was performed with PBS $(3 \times 25 \mathrm{~mL})$. The BAL underwent a low-speed spin $(400 \times g)$ to separate out cells and particulates.

Inflammatory and biochemical assays. Neutrophils were isolated from unventilated control pigs, and neutrophil chemotaxis assays (NCAs) were performed as previously described (15). The concentration of total protein in BAL fluid was quantified using the Pierce bicinchoninic acid (BCA) microtiter technique (16). IL-8 and TNF- $\alpha$ (two cytokines routinely isolated in lung injury models) concentrations were assayed utilizing a commercially available enzyme-linked immunosorbent assay kit (ELISA) (Quantikine Porcine, R\&D Systems, Minneapolis, MN).

Endogenous $\mathrm{CC} 10$ and $\mathrm{PLA}_{2}$ activity was measured in meconium samples from five healthy term infants. Meconium was suspended in PBS, $\mathrm{pH} 7.4$, in a consistent weight: volume (e.g. $50 \mathrm{mg}$ in $200 \mu \mathrm{L}$ ), mixed thoroughly, and then debris pelleted at $12,000 \times g$ in a microfuge for $2 \mathrm{~min}$. Total protein was determined by micro-BCA assay (Pierce Chemical Co.) and $\mathrm{sPLA}_{2}$ concentration and activity were measured using an ELISA kit specific for $\mathrm{SPLA}_{2}$ type 2a and a $\mathrm{SPLA}_{2}$ activity assay kit (both from Cayman Chemical Co.). CC10 content was determined using a competitive ELISA for CC10 previously described (15).

The biologic activity of rhCC10 was quantified using a novel $\mathrm{sPLA}_{2}$ inhibition assay. rh-sPLA $A_{2}$ type $1 \mathrm{~b}$ was kindly provided by Dr. Wonwha Cho (University of Illinois at Chicago). In this assay, the rh-sPLA 2 type $1 \mathrm{~b}$ hydrolyzes a specific fluorescent substrate (UNIBIPY; Molecular Probes, Inc.). Reactions were performed in Hanks balanced salt solution (HBSS), $\mathrm{pH}$ 7.4, with $1 \mathrm{mM} \mathrm{CaCl}_{2}$. The ratio of rhCC10 to rh-sPLA $\mathrm{A}_{2}$ type $1 \mathrm{~b}$ was fixed at $30: 1$ and the rhCC10 and rh-sPLA 2 type $1 \mathrm{~b}$ were preincubated for $20 \mathrm{~s}$ at $37^{\circ} \mathrm{C}$ before addition of the substrate (116 $\mu \mathrm{M}$ UNIBIPY). Reactions were stopped by adding a stopping solution containing an 8:3 mix of 2-propanol:n-hexane. Cleavage products were readily separated using normal phase highperformance liquid chromatography (2-propanol:n-hexane:water 8:3:2 solvent system; Waters Spherisorb Silicon, 5- $\mu \mathrm{m}$ column) and characterized using fluorescence detection (excitation $480 \mathrm{~nm}$, emission $517 \mathrm{~nm}$ ). Retention time for UNIBIPY substrate was about 7-8 min, and for product, it was 19-20 min. Inhibition of rh-sPLA $\mathrm{P}_{2}$ type $1 \mathrm{~b}$ by rhCC10 is highly reproducible, typically $>75 \%$. Reaction products were quantitated using HP software to determine the areas of substrate and product peaks.
Statistical methods. Statistical analysis was performed using the SAS System. Analysis of variance (ANOVA) was conducted to examine changes over time within each group. Two-tailed paired or unpaired $t$ tests examined differences between groups. A $p$ value $<0.05$ was considered statistically significant. Data are presented as mean $\pm \mathrm{SD}$.

\section{RESULTS}

Physiologic measurements. Alveolar-to-arterial (A-a) gradients before meconium instillation were comparable in the control and rhCC10 groups $(22 \pm 9$ and $47 \pm 59 \mathrm{~mm} \mathrm{Hg}$, respectively). After the instillation of meconium and surfactant, the gradients rose significantly in both the control and rhCC10 groups ( $119 \pm 56$ and $113 \pm 78 \mathrm{~mm} \mathrm{Hg}$, respectively; $p<0.05$ compared with baseline). At $24 \mathrm{~h}$, there were no significant differences in the peak inspiratory pressures or inspiratory times between groups. A-a gradients were not statistically different between the control and rhCC10 groups $(104 \pm 105$ and $130 \pm 181 \mathrm{~mm} \mathrm{Hg}$, respectively). Lung weights were also similar in the control and rhCC10 groups $(40 \pm 13 \mathrm{~g}$ and $35 \pm 10 \mathrm{~g}$, respectively). Pressure-volume curves were generated and revealed no difference between CC10-treated and untreated groups, suggesting that surfactant function was comparable between groups.

Biochemical assays. TAF cell counts could not be performed at $24 \mathrm{~h}$ due to significant debris from the meconium present in the cell pellet. IL-8 measurements were $406 \pm 364$ and $408 \pm 526$ at time 0 and increased to $4837 \pm 1950 \mathrm{pg} / \mathrm{mg}$ protein $/ \mathrm{mL}$ and $5554 \pm 2895$ for control and rhCC10-treated groups, respectively. This represents a 12 -fold increase from baseline to $24 \mathrm{~h}$, with no statistically significant difference seen between CC10-treated and untreated groups (Table 1). TNF- $\alpha$ measurements were similar between groups at time 0 , but by $24 \mathrm{~h}$, control animals had a 17 -fold increase while the rhCC10-treated animals had only a 10-fold increase ( $p<$ 0.05) (Table 1).

In TAF collected at baseline (before meconium administration), a low level of CC10 background could be detected (mean, $19.1 \pm 15.9 \mathrm{ng} / \mathrm{mL}$; range, 6.8-68.5). Twenty-four hours following meconium instillation, CC10-treated piglets had a mean of $2600 \pm 5800 \mathrm{ng} / \mathrm{mL}$, while the placebo animals had a mean of $38.9 \pm 59.9 \mathrm{ng} / \mathrm{mL}$. The background level of CC10 (measured by the ELISA), doubled in the first $24 \mathrm{~h}$ following meconium instillation, presumably due to crossreactivity with endogenous piglet $\mathrm{CC} 10$. Mean $\mathrm{SPLA}_{2}$ activity

Table 1. Inflammatory markers in TAF, BAL, and serum

\begin{tabular}{lccccc}
\hline & \multicolumn{2}{c}{ Time $0 \mathrm{~h}$} & & \multicolumn{2}{c}{ Time $24 \mathrm{~h}$} \\
\cline { 2 - 3 } \cline { 5 - 6 } \cline { 5 - 6 } & Control & rhCC10 & & Control & rhCC10 \\
\hline Total protein & $0.34 \pm 0.012$ & $0.52 \pm 0.24$ & & $1.54 \pm 0.90$ & $1.41 \pm 0.70$ \\
TA IL-8 & $406 \pm 364$ & $408 \pm 526$ & & $4837 \pm 1951$ & $5554 \pm 2895$ \\
TA TNF- $\alpha$ & $80 \pm 84$ & $57 \pm 59$ & & $1357 \pm 676^{*}$ & $561 \pm 321^{*}$ \\
Serum TNF- $\alpha$ & $27 \pm 10$ & $28 \pm 5$ & & $72 \pm 81$ & $36 \pm 26$ \\
BAL NCA & & & & $42 \pm 25$ & $29 \pm 18$ \\
\hline
\end{tabular}

There were no differences seen in total protein levels, IL-8 levels, or neutrophil chemotaxis activity between groups. There is a significant decrease in TAF TNF- $\alpha$ levels $(p<0.05)$ and a trend toward decreased serum TNF- $\alpha$ levels $(p>0.05)$ in piglets following rhCC10 administration. TA, tracheal aspirate.

$* p<0.05$ in control vs rhCC10. 
in the baseline pooled TA sample (equal mixture of all 16 piglets) was $0.64 \mathrm{nmol} / \mathrm{min}$. Mean $\mathrm{SPLA}_{2}$ activity in $24 \mathrm{~h} \mathrm{TAF}$ showed no significant difference between controls $(0.97 \pm$ $0.29 \mathrm{nmol} / \mathrm{min})$ and CC10-treated animals $(0.99 \pm 0.43 \mathrm{nmol} /$ min). Therefore, $\mathrm{sPLA}_{2}$ activity in TAF increased $44 \%$ between baseline and $24 \mathrm{~h}$, irrespective of treatment group.

Serum. IL-8 levels were undetectable in serum. Although TNF- $\alpha$ levels were similar at time $0(27 \pm 10$ and $28 \pm 5$ $\mathrm{pg} / \mathrm{mL}$ ), by $24 \mathrm{~h}$, serum levels in the control animals had increased almost threefold while rhCC10-treated animals had remained the same (Table 1). These values were not statistically significant due to biologic variability. CC10 was detectable in serum at $24 \mathrm{~h}$ in both control $(3-6 \mathrm{ng} / \mathrm{mL}$ "background") and CC10-treated piglets (220-230 ng/mL).

$\boldsymbol{B A L}$. IL-8 was undetectable in BAL, and there were no differences between groups in TNF- $\alpha$ levels at $24 \mathrm{~h}$. NCA measurements on concentrated BAL were $42 \pm 25 \%$ in controls and $29 \pm 18 \%$ in the rhCC10-treated animals. Although this 50\% difference favored the rhCC10 treatment group, these values did not reach statistical significance, again due to biologic variability.

Meconium. The mean CC10 concentration in normal newborn meconium was $18.8 \pm 5.2 \mathrm{ng} / \mathrm{mg}$ meconium (soluble fraction only, $n=5$ ). The mean SPLA $_{2}$ activity was $5.7 \pm 3.5$ $\mathrm{nmol} / \mathrm{min}$ in meconium $(n=5)$. Mean concentration of $\mathrm{sPLA}_{2}$ type $2 \mathrm{a}$ was $20.5 \pm 7.6 \mathrm{pg} / \mathrm{mg}$ of meconium $(n=7)$. Total protein was consistent between meconium extract samples, and the mean was $18.3 \pm 8.0 \mu \mathrm{g} / \mathrm{mg}$ meconium $(n=5)$. We found no correlation between the amount of endogenous $\mathrm{CC} 10$ and the level of $\mathrm{PLA}_{2}$ activity in meconium.

Histopathology. Histopathology revealed significant pneumonitis in all untreated and rhCC10-treated piglets (Fig. 1). Polymorphonuclear cells and edema were seen in the alveolar spaces in addition to thickened cellular walls. The lungs contained significant cellular debris and mucus. There were patchy areas of pneumonitis alternating with areas of severe

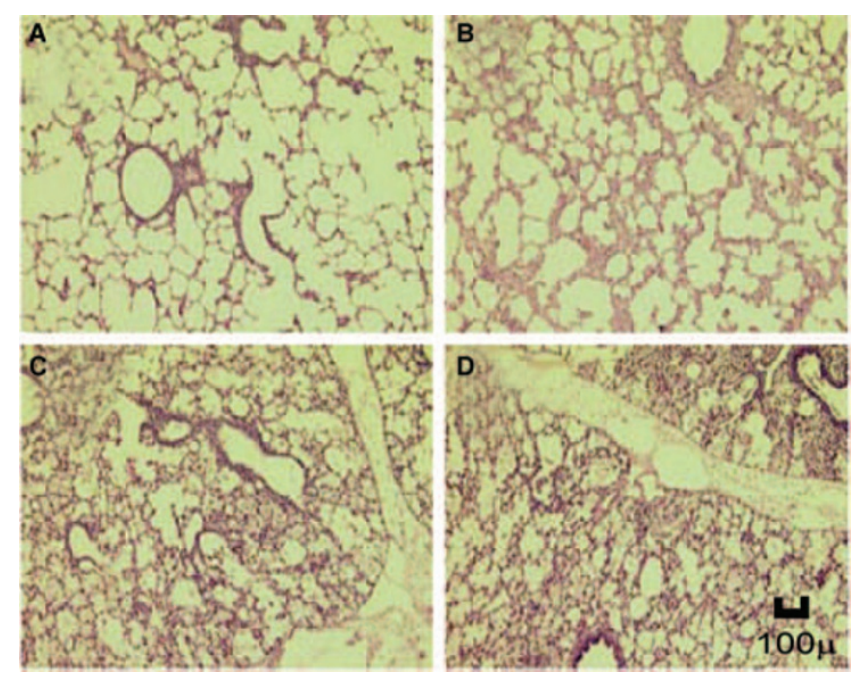

Figure 1. Lung histology after meconium aspiration. (A) Normal piglet lung (2-4 d old). (B) Diffuse septal thickening without evidence of meconium. (C, $D$ ) Significant neutrophil infiltration, mucus production, and squamous cell accumulation in both control and rhCC10-treated piglets. Scale bar $=100 \mu \mathrm{m}$. Magnification is $\times 100$. atelectasis and normal lung. Areas without evidence of pneumonitis still showed thickening of the alveolar walls. There were no qualitative differences between control and rhCC10treated groups.

\section{DISCUSSION}

MAS was induced in our piglet model and treated with a combination of surfactant and rhCC10 or placebo. rhCC10treated animals had significantly less TNF- $\alpha$ in their TAF compared with placebo controls at $48 \mathrm{~h}$. TNF- $\alpha$ is a cytokine that has multiple proinflammatory effects, acting locally as a paracrine and autocrine regulator of leukocytes and endothelial cells (17). The principal actions of TNF- $\alpha$ include increased expression of adhesion molecules, activation of lymphocytes, and increased cytokine production by mononuclear cells. TNF- $\alpha$ enhances the synthesis of CC10 in cell culture models by stabilizing CC10 mRNA, suggesting that a physiologic role for $\mathrm{CC} 10$ is down-regulation of TNF- $\alpha$-induced inflammation (4). Meconium has been shown to induce TNF- $\alpha$ secretion in bronchial epithelial cells, suggesting that TNF- $\alpha$ is an important mediator of chemical pneumonitis and the inflammatory response in MAS (18).

This is the first report of CC10 activity in normal newborn meconium. Its presence is not surprising since $\mathrm{CC} 10$ rises to $1 \mu \mathrm{g} / \mathrm{mL}$ in amniotic fluid after $32 \mathrm{wk}$ of gestation as a result of fetal lung maturation (19). CC10 was shown previously to inhibit $\mathrm{SPLA}_{2}$ protein in vitro $(6,20)$, yet the CC10 in meconium was not sufficient to completely inhibit $\mathrm{PLA}_{2}$ activity. Moreover, soluble $\mathrm{PLA}_{2}$ activity increased an average of $44 \%$ in TAF samples from both treatment groups $24 \mathrm{~h}$ after meconium instillation. It is not clear whether the increase in $\mathrm{PLA}_{2}$ activity was due to the instillation of the meconium or whether overall activity level was augmented by host $\mathrm{SPLA}_{2}$ released as part of the inflammatory response. Nevertheless, there were no differences in levels of $\mathrm{PLA}_{2}$ activity between the control and rhCC10-treated groups, despite the fact that rhCC10 demonstrated potent inhibition of $\mathrm{SLA}_{2}$ activity in vitro. This suggests that that the decrease in TNF- $\alpha$ concentrations in TAF from the treated group was not due to the ability of rhCC10 to inhibit $\mathrm{SPLA}_{2}$ activity in vivo.

Meconium reportedly contains significant amounts of IL-8, sufficient to mediate neutrophil chemotaxis (21). While we did not find detectable levels of IL-8 in serum from meconiumtreated piglets, elevated IL- 8 in was found in TAF from meconium-treated piglets. In contrast, inflammatory responses that illicit IL-8 release in the lungs typically result in significant systemic levels as well. This result is consistent with a previous report of the highly localized nature of the inflammatory response to meconium in piglets (22).

The present study illustrates that meconium aspiration elicits a potent inflammatory response in which $\mathrm{SPLA}_{2}$ activity, IL-8, and TNF- $\alpha$ in TAF were elevated $24 \mathrm{~h}$ post-instillation. It was somewhat surprising that only the local and systemic TNF- $\alpha$ response, and not IL- 8 or sPLA ${ }_{2}$ activity levels, was suppressed by rhCC10. It is possible that timing of peak responses were missed in this "snapshot" or the dose was insufficient to completely inhibit the inflammatory response 
and/or sPLA $_{2}$ activity. Previous studies have suggested a strong linkage between SPLA $_{2}$ enzyme activity and TNF- $\alpha$ levels, TNF- $\alpha$ signaling and IL-8 transcription, and sLA $_{2}$ activity and IL- 8 activation during inflammatory responses to a variety of stimuli (23). Similarly, $\mathrm{sPLA}_{2}$ protein can act as a ligand for the M-type $\mathrm{SPLA}_{2}$ receptor in bronchial epithelial cells and human lung macrophages, stimulating $\mathrm{CPLA}_{2}$ activation and initiation of the arachidonic acid cascade, resulting in synthesis of eicosanoid mediators and the release of IL-8 and TNF- $\alpha(23,24)$.

Our NCA did reveal a decreased chemoattractant capability of the BAL in rhCC10-treated animals compared with placebo controls, although the values failed to reach statistical significance. Given the incomplete suppression of the overall inflammatory response by rhCC10 in this model, it is not surprising that the chemoattractant capability of BAL was blunted, but not significantly reduced, in CC10-treated animals.

Surfactant, like meconium, is a very complex mixture of components and the anti-inflammatory properties of exogenous lung surfactant must also be considered (25). All animals received exogenous surfactant after meconium instillation, since this treatment is now considered routine. A standard dose of surfactant contains at least fourfold more surfactant than a full-term lung (26) and may largely overcome the phospholipase activity of the meconium and ameliorate inactivation of endogenous surfactant. The anti-inflammatory properties of the surfactant itself may have masked the full inflammatory response, explaining the differences between the IL-8, sPLA ${ }_{2}$, and TNF- $\alpha$ responses.

It is of interest that histopathologic analysis revealed areas of alveolar wall thickening in areas where there was no evidence of pneumonitis. Other sections from the same lungs did have pneumonitis, suggesting that the inflammatory response from the areas with active disease caused cytokineinduced lung injury, resulting in hyperplasia (27). IL-8 is not only a potent neutrophil chemoattractant, but also stimulates infiltration by fibroblasts (28), which could account for the generalized thickening observed in both treatment groups. The physiologic advantage of this type of hyperplasia might be to provide a greater capacity to absorb and remove the particulate debris.

Our experimental period of $24 \mathrm{~h}$ was also relatively short considering that MAS develops over a variable period of time, often being initiated in utero and increasing in severity in the days following birth. At $24 \mathrm{~h}, \mathrm{CC} 10$ levels were doubled in untreated animals and were increased by 137 fold after $\mathrm{CC} 10$ treatment. This suggests that the CC10 remains present and may have more biologic and physiologic effects if the exposure is longer. The maximal antiinflammatory effects of rhCC10 (e.g. decreased total cell counts in TAF, particularly neutrophils) in premature human infants were observed $48-72 \mathrm{~h}$ after rhCC10 administration (13). Likewise, the maximal anti-inflammatory effects of rhCC10 in ventilated newborn piglets were observed at $48 \mathrm{~h}$, but not $24 \mathrm{~h}$ post-administration (15). The lack of in utero effects and short experimental period represent major limitations of the piglet model.
In conclusion, i.t. administration of rhCC10 to piglets with MAS significantly reduced the amount of TNF- $\alpha$ in TAF, without affecting IL-8 or $\mathrm{SPLA}_{2}$ activity. The nature of the inflammatory response in MAS, the relatively short experimental period $(24 \mathrm{~h})$, the lack of in utero hypoxia, and the use of exogenous surfactant contribute to this complicated picture and represent limitations of the model. Both meconium and surfactant contain components that trigger numerous pro- and anti-inflammatory cellular pathways simultaneously. More detailed studies will be required to further delineate the antiinflammatory pathways of rhCC10 action in this model.

Acknowledgments. The authors thank Ellen Gurzenda, Hshi-Chi Koo, Jeffrey Kazzaz, and Lynda Adrouche-Amrani, M.D., for their expert technical assistance. They also gratefully acknowledge the contribution of Simcha Pollack, Ph.D., for his assistance with statistical analysis.

\section{REFERENCES}

1. Yoder BA, Kirsch EA, Barth WH, Gordon MC 2002 Changing obstetric practices associated with decreasing incidence of meconium aspiration syndrome. Obstet Gynecol 99:731-739

2. Tyler DC, Murphy J, Cheney FW 1978 Mechanical and chemical damage to lung tissue caused by meconium aspiration. Pediatrics 62:454-459

3. Holopainen R, Aho H, Laine J, Peuravuori H, Soukka H, Kaapa P 1999 Human meconium has high phospholipase A2 activity and induces cellular injury and apoptosis in piglet lungs. Pediatr Res 46:626-632

4. Yao XL, Levine SJ, Cowan MJ, Logun C, Shelhamer JH 1998 Tumor necrosis factor-alpha stimulates human Clara cell secretory protein production by human airway epithelial cells. Am J Respir Cell Mol Biol 19:629-635

5. Ward M, Sinn J 2003 Steroid therapy for meconium aspiration syndrome in newborn infants. Cochrane Database Syst Rev CD003485

6. Levin SW, Butler JD, Schumacher UK, Wightman PD, Mukherjee AB 1986 Uteroglobin inhibits phospholipase A2 activity. Life Sci 38:1813-1819

7. Pilon AL 2000 Rationale for the development of recombinant human CC10 as a therapeutic for inflammatory and fibrotic disease. Ann N Y Acad Sci 923:280-299

8. Zhang Z, Kundu GC, Yuan CJ, Ward JM, Lee EJ, DeMayo F, Westphal H, Mukherjee AB 1997 Severe fibronectin-deposit renal glomerular disease in mice lacking uteroglobin. Science 276:1408-1412

9. Johnston CJ, Mango GW, Finkelstein JN, Stripp BR 1997 Altered pulmonary response to hyperoxia in Clara cell secretory protein deficient mice. Am J Respir Cell Mol Biol 17:147-155

10. Miller TL, Shashikant BN, Melby JM, Pilon AL, Shaffer TH, Wolfson MR 2005 Recombinant human Clara cell secretory protein in acute lung injury of the rabbit: effect of route of administration. Pediatr Crit Care Med 6:698-706

11. Nosratabadi AR, Ljungman AG, Lindahl M, Welch R, Pilon A, Tagesson C 2003 Clara cell 10-KDA protein inhibits endotoxin-induced airway contraction in isolated perfused rat lungs. Exp Lung Res 29:455-473

12. Wang SZ, Rosenberger CL, Bao YX, Stark JM, Harrod KS 2003 Clara cell secretory protein modulates lung inflammatory and immune responses to respiratory syncytial virus infection. J Immunol 171:1051-1060

13. Levine CR, Gewolb IH, Allen K, Welch RW, Melby JM, Pollack S, Shaffer T, Pilon AL, Davis JM 2005 The safety, pharmacokinetics, and anti-inflammatory effects of intratracheal recombinant human Clara cell protein in premature infants with respiratory distress syndrome. Pediatr Res 58:15-21

14. Davey AM, Becker JD, Davis JM 1993 Meconium aspiration syndrome: physiological and inflammatory changes in a newborn piglet model. Pediatr Pulmonol 16:101-108

15. Chandra S, Davis JM, Drexler S, Kowalewska J, Chester D, Koo HC, Pollack S, Welch R, Pilon A, Levine CR 2003 Safety and efficacy of intratracheal recombinant human Clara cell protein in a newborn piglet model of acute lung injury. Pediatr Res 54:509-515

16. Smith PK, Krohn RI, Hermanson GT, Mallia AK, Gartner FH, Provenzano MD, Fujimoto EK, Goeke NM, Olson BJ, Klenk DC 1985 Measurement of protein using bicinchoninic acid. Anal Biochem 150:76-85

17. Vassalli P 1992 The pathophysiology of tumor necrosis factors. Annu Rev Immunol 10:411-452

18. Berdeli A, Akisu M, Dagci T, Akisu C, Yalaz M, Kultursay N 2004 Meconium enhances platelet-activating factor and tumor necrosis factor production by rat alveolar macrophages. Prostaglandins Leukot Essent Fatty Acids 71:227-232

19. Bernard A, Thielemans N, Lauwerys R, Langhendries JP, Van Lierde M, Freund MM 1994 Clara cell protein in human amniotic fluid: a potential marker of fetal lung growth. Pediatr Res 36:771-775

20. Mantile G, Miele L, Cordella-Miele E, Singh G, Katyal SL, Mukherjee AB 1993 Human Clara cell $10-\mathrm{kDa}$ protein is the counterpart of rabbit uteroglobin. J Biol Chem 268:20343-20351 
21. de Beaufort AJ, Pelikan DM, Elferink JG, Berger HM 1998 Effect of interleukin 8 in meconium on in-vitro neutrophil chemotaxis. Lancet 352:102-105

22. Korhonen K, Soukka H, Halkola L, Peuravuori H, Aho H, Pulkki K, Kero P, Kaapa PO 2003 Meconium induces only localized inflammatory lung injury in piglets. Pediatr Res 54:192-197

23. Jo EJ, Lee HY, Lee YN, Kim JI, Kang HK, Park DW, Baek SH, Kwak JY, Bae YS 2004 Group IB secretory phospholipase A2 stimulates CXC chemokine ligand 8 production via ERK and NF-kappa B in human neutrophils. J Immunol 173:64336439

24. Granata F, Petraroli A, Boilard E, Bezzine S, Bollinger J, Del Vecchio L, Gelb MH, Lambeau G, Marone G, Triggiani M 2005 Activation of cytokine production by secreted phospholipase A2 in human lung macrophages expressing the M-type receptor. J Immunol 174:464-474
25. Talati AJ, Crouse DT, English BK, Newman C, Livingston L, Meals E 1998 Exogenous bovine surfactant suppresses tumor necrosis factor-alpha release by murine macrophages stimulated by genital mycoplasmas. J Infect Dis 178:11221125

26. Janssen DJ, Tibboel D, Carnielli VP, van Emmen E, Luijendijk IH, Darcos Wattimena JL, Zimmermann LJ 2003 Surfactant phosphatidylcholine pool size in human neonates with congenital diaphragmatic hernia requiring ECMO. J Pediatr 142:247252

27. Halbertsma FJ, Vaneker M, Scheffer GJ, van der Hoeven JG 2005 Cytokines and biotrauma in ventilator-induced lung injury: a critical review of the literature. Neth J Med 63:382-392

28. Vaillant P, Menard O, Vignaud JM, Martinet N, Martinet Y 1996 The role of cytokines in human lung fibrosis. Monaldi Arch Chest Dis 51:145-152 